\title{
Policy making and energy infrastructure change: a Nigerian case study of energy governance in the electricity sector
}

\author{
Norbert Edomah ${ }^{1,2}$, Chris Foulds², and Aled Jones ${ }^{2}$ \\ ${ }^{1}$ Pan-Atlantic University, Lagos Nigeria.. \\ 2 Global Sustainability Institute, Anglia Ruskin University, Cambridge, United Kingdom. \\ Email: nedomah@pau.edu.ng; chris.foulds@anglia.ac.uk; Aled.jones@anglia.ac.uk.
}

\begin{abstract}
This paper focusses on investigating the underlying mechanisms and influences of the policy decision making process and how it affects and impacts the governance of the Nigerian energy industry, and energy infrastructure provisions. In-depth semistructured interviews were used; all interviewees had been involved, directly or indirectly, in energy infrastructure policy decisions in Nigeria. Five key themes subsequently emerged as salient intra-country induced influences that were affecting the governance and performance of the Nigerian energy sector: (1) competencies i.e. practical knowledge of energy policy making; (2) expectations - i.e. past, present, and forecasted future expectations from the energy industry; (3) legislation - i.e. institutionalized (and unwritten) rules/procedures; (4) future visions - i.e. future vision of the energy industry/energy market; (5) recruiting experts - i.e. recruiting new energy and public policy makers. In addition, three major inter-country induced influences were also identified: (1) the changing dynamics of international and foreign aid; (2) the United Nations Sustainable Development Goals; and (3) the Paris Agreements on Climate Change. The paper concludes by highlighting the policy implications of these influences, and the consequences for policy makers in the governance of the energy industry in ensuring a secured energy future.
\end{abstract}

\section{Keywords}


Energy market; Energy governance; Energy systems; Public policy; Developing countries; Sub-Sahara Africa.

\section{INTRODUCTION}

There is certainly a need to focus on how energy is supplied, as part of minimizing the impact of various environmental problems, such as: pollution, global warming, climate change, natural resource depletion, and loss of biodiversity, to name a few (US EPA, 2016). This presents an interesting platform to highlight the political and policy opportunities that come with examining the supply side of energy (Schock and Sims, 2007). What are the implications of the transitions that are going on in many parts of the world in relation to energy dynamics? What are the implications of constancy within global energy policy? What are the policy interests of most nations? What is going on within the global energy market? Does it continue to be constant? These questions are important in exploring the learnings from the historical effects of policy decisions which can guide current and future policy makers (and other relevant stakeholders) in making the most appropriate choices, albeit still inevitably with unintended consequences (Doukas et al., 2008).

The increasing role of governments in energy decisions cannot be overemphasized (Florini and Sovacool, 2009). This is enacted through regulations and other forms of controls they have in the energy market (European Union, 2015). However, do policy makers understand energy well enough to make smart decisions? What impact has the policy making process had on energy policy and energy infrastructure provision over time (in developed and developing countries)? Not enough research has been done that links policy decision dynamics and their influences on energy infrastructure 
provision and energy policy from a developing country perspective (Doukas and Ballesteros, 2015). Bale (2015) argues that social and institutional elements needs to be incorporated when addressing questions at the technology-policy-behaviour interface. Connors (2015) also argues that energy is an essential component of economic development, and energy sector decisions and practices will play a central role in determining the sustainability of development in every country, region and sector. Some sectors that influences and impact energy infrastructure provision such as: transport; industry (manufacturing); residential; and resource extraction and production (such as mining activities) - also informs the policy decisions of the government in this regard (Schock and Sims, 2007).

This paper empirically explores the role and influences of the historical policy decisions process(es), how they influenced transition in energy infrastructure provision, and their corresponding impact on energy policy transitions by seeking to answer the question:

- What exactly constitutes the practice and process of policy making, and how does this influence energy supply infrastructure provision and energy policy?

Doukas et al. (2008) argues that in the policy framework, energy policy should compromise desirable objectives and encourage close collaboration between current stakeholders who are also key energy players (e.g. energy users, energy companies, government), in order to confront and tackle the various obstacles. This is important in studying the Nigerian case as there seems to be a general hypothesis 
that the lingering challenges in the Nigerian energy sector were aggravated by two major issues:

- Insufficient stakeholder engagement: It is generally believed that conversation with stakeholders, getting them involved and buying into the target plan or goal have not been sufficiently done in the past. Stakeholder engagement decayed over time, which led to failure of consensus agreement on policy plans and implementation (Alberta Energy Regulator, 2015; Sherriff, 2012).

- Challenges in taking decisions: Decision making, particularly with respect to formulation and implementation of policies, driven by strategic energy plan(s) with stakeholder involvement still remains a challenge (Cockrel, 1997; Kunreuther and Weber, 2014). However, this challenge varies in terms of scope, extent, scale, and ripple effects, when viewed at the sub-sector level, (e.g. mining, oil and gas, electrical power sectors).

The aforementioned are important particularly in addressing issues of energy infrastructure provision, climate policy, climate change, energy investment, and other interconnected issues (Reddy et al., 2000).

This paper begins with outlining the research context (section 2), specifically by highlighting some of the underlying dynamics that pose themselves as influences in the governance of energy, in addition, to detailing relevant global energy policy phases across the $20^{\text {th }}$ century. Methodological considerations are then presented (section 3) before the salient intra-country and inter-country induced factors influencing the Nigerian energy industry performance are discussed (sections 4 and 
5); including discussions of how policy decision dynamics impacted on the Nigerian energy industry. This paper then concludes by highlighting some concerns and uncertainties associated with the influences of the policy decision process in the governance of energy going forward (section 6).

\section{RESEARCH CONTEXT}

Whilst individuals, institutions, and countries may change and evolve over time, our modern society will still continue to need energy, not only consistently, but also affordably and safely, regardless of the inevitable transitions in energy supply, use, and geopolitics that are occurring around us (World Economic Forum, 2013). The uncertainty that comes with oil politics is not a reason for many big oil players to stay

out of a country (Bromley et al., 2006). These such companies have been shown to historically invest wherever oil and gas resources are, provided the contract terms, the laws, and the regulations, provides for an economically attractive return. Indeed, most energy investors, due to limited resources, focus on investing their resources in places where it makes the most economic sense (Naudé and Krugell, 2007). They invest in places that understand that the terms for investment are mutually beneficial and sustainable in the long term, despite the institutional, regulatory, and infrastructural constraints that constitute business risks. Ownership also constitutes a business risk as most oil and gas fields are owned by state or state owned corporations which implies that most energy investment decisions will not only be based on commercial viability, but primarily on the national energy priorities of the given country (Caron and Paradis, 2011). Investments today therefore tend to focus on places that understand that a balanced partnership increases the value of the 
enterprise for all parties. As such, one of the key drivers of current and future investment for most oil and gas players lies in the policy direction of the target countries, irrespective of the short term political changes that every country faces (Stevens and Hulbert, 2012).

Fortunately, the world is not running out of oil (WSJ, 2014), however, the unfortunate situation is that the world will never have enough. Indeed, the world is still nearly completely based on oil for transportation (Dineen et al., 2014). As long as we keep monopolizing the transport industry with a single fuel, such as oil, we are not going to meet the current projections for energy demand (IHS Global Inc, 2013). The politics of energy will never permit us to have enough energy for the growing demand. For example, the geo-politics of energy, and of oil in particular, has been shown to frequently constrain how, where, and what energy is provided to given countries (Bromley et al., 2006). Such constraints may come to be in a variety of ways, such as: an accidental fate resulting to the suspension of operating permits in certain countries around the world; the threats that exists (verbal or otherwise) that sends shock waves through the oil prices to disable economic growth projections of countries that otherwise would be able to grow faster; among others. Ultimately, the geopolitical issues present policymakers, and energy stakeholders more broadly, with an uncertain future (PWC, 2013; Verrastro et al., 2010).

In the past, it has been argued that changes in the energy market and infrastructure were more on market principles. In recent times, however, energy policies have been increasingly influenced by issues relating to security of supply, environmental protection, and energy market competitiveness. Doukas et al (2008) have described 
the evolution in the process and foci of energy policy during the $20^{\text {th }}$ century, as part of three distinct phases:

1. Energy abundance period (until the first oil crisis in 1974) - this period was characterized by increased energy demand, increased energy consumption, and increased economic growth. There were no serious energy policies until the oil crisis when governments were forced to have clear policy frameworks to protect and strengthen the energy market both in the short and long term (Hoffman, 2014).

2. Energy insufficiency period (until 1985) posing the need for reduced energy dependence - this period was characterized by increased policy focus on energy efficiency, energy conservation, energy savings, and energy management with emphasis on the rational use of energy.

3. Energy balance period (up to 2000) - this period was characterized by increased focus on energy environmental policies to protect the severe impact of excessive production and consumption activities on the environment.

There are lots of influences that govern the provision of energy infrastructure (Markard, 2011). One of the biggest stakeholders in the value chain of energy infrastructure provisions is policy makers (Verrastro et al., 2010). Understanding their role in the policy decision process and how it affects energy infrastructure provision is critical if we are to have a better understanding of the wider range of influences and actors governing energy transitions (Platzer, 2015; Scott et al., 2011). In selecting a case study to more deeply explore such issues, the unique history of energy in Nigeria (and its associated political influences makes it both a unique case 
with lots of applicable lessons for other developing and emerging countries (Edomah et al., 2016a).

\section{METHODOLOGY}

Semi-structured interviews were used to investigate past and current policy making dynamics in Nigeria with respect to energy. Interviews were adopted because doing a one-to-one interview is easier and more practical when dealing with policy makers (Kumar, 2013; Tansey, 2007), mainly because it facilitates interaction and allows trust to be built (as sensitive issues may need to be discussed). The interviewees were selected on the basis of involvement (directly or indirectly) either in the policy making process, or their role in connection with energy supply infrastructure provision. An interview protocol, with pre-determined list of suggested questions and prompts, was designed as a guide for the interview.

Notes of very important points (interview notes) were taken during each interview rather than audio recording each interview (Clausen, 2012). This approach was essential in encouraging the interviewees to be open and speak freely. This is quite important in the cultural context of Nigeria, where people can be quite reserved when they discover that they are being recorded (Halcomb and Davidson, 2006). The data (interview notes) collected (using pen and paper during the interviews) were transcribed and expanded upon immediately after the interviews, in order to ensure that the vital points discussed during the interviews were captured. 
In analysing the data, an initial quick read-through of the interview notes was done, which primarily involved making notes of initial reactions and impressions. Following that, labelling and coding of relevant pieces such as phrases, words, sentences and statements was conducted. The labels were: activities, concepts, opinions, differences, and processes (Khandkar, 2009).

After the initial labelling/coding, decisions were taken on the most important codes (creating categories by bringing several codes together). This was done by filtering out less relevant codes and by combining existing codes to create new codes. Important codes were kept together and grouped as needed to create categories (themes). Relevant categories that are connected with each other were labelled (which describes the connection between categories). The categories and connections are the main results of the study (McAdams, 1980). It is new knowledge about the world from the perspective of the participants in the study. Table 1 presents a brief background and experience of some of the interviewees interviewed while this research was being carried out.

\section{INTRA-COUNTRY INDUCED FACTORS INFLUENCING THE NIGERIAN ENERGY INDUSTRY PERFORMANCE}

The analysis of the interview notes yielded five main themes, which stood out as the key intra-country induced factors that were influencing the Nigerian energy industry performance. These five themes, which give a better understanding of the internal processes and practice of energy-related are: 
1 Competencies, - i.e. practical knowledge of energy policy making.

2 Expectations, - i.e. past, present and future expectations from the energy industry.

3 Legislation, - i.e. institutionalized (and unwritten) rules/procedures in the energy industry.

4 Future visions, - i.e. future visions of the energy industry/energy market.

5 Recruiting experts, - i.e. recruiting new energy and public policy makers.

The following sub-sections $(4.1-4.5)$ expand on each of these themes in turn, including presenting evidence for how they have influenced, and are influencing, the Nigerian energy industry's performance and development via policymaking.

\subsection{Competencies - practical knowledge of energy policy making.}

The first of the key influences resulting from the research is energy competency which presents itself in the form of lack of knowledge and competencies in energy policy making (Hood et al., 2002). Competencies entail the practical ability to use and apply related skills, abilities, and knowledge in order to perform a defined task or critical work function. In the same way, energy-related competencies entail all the requisite skills and abilities required to successfully manage and govern the affairs in the energy industry (Van Vooren, 2011).

There are two essential areas of competency that need to reflect the skills set of those involved in energy policy making and the governance of energy infrastructure provision. 
- Planning for our energy future - involves formulation and implementation of strategies, innovation, creativity, and change orientation (Great Britain Department of Trade and Industry, 2003).

- Engaging stakeholders - includes communication, consultations, building relationships, and providing leadership (Conde et al., 2004; UNEP, 2011).

This study reveals that, within the Nigerian context, energy competency challenge manifests in three ways:

- Non-professionals actors appointed as energy ministers, who try to adopt a dogmatic approach in addressing the problems in the sector. This leadership approach only led to a 'watch and see if this will work' syndrome by many stakeholders in that industry, which eventually led to further failure and decay of the Nigerian energy sector (Whitmarsh et al., 2009).

- Employing the services of people in the legal profession (for preparation and drafting of energy policies) who neither have the requisite knowledge, nor understand the workings of the energy sector and the global norms and regulations governing the sectors activities (Florini and Sovacool, 2009). A very good example of a lack of such competence is reflected in the removal of maximum demand charge on electricity for industrial user in Nigeria during the sector reforms which started in earnest in 2005. This example contradicts the global norm as it is common in the global electricity supply industry to include a maximum demand charge in order to discourage industrial users from consistently reaching the maximum peak demand for electricity (We Energies, 
2015). This is also practiced in different countries as it is a general rule in electrical engineering.

- Ignoring the inputs of those who have been involved in the historical development (and decay) of the current energy supply infrastructure.

The importance of engaging and aligning with stakeholders cannot be overemphasized (Goldthau, 2014). In the past, there used to be some degree of alignment between policy makers (through designated governments institutions) and those responsible for maintaining the existing energy infrastructure network, as was the case with the then National Electrical Power Authority (NEPA), and the Ministry of Establishments (which is an arm of the federal government of Nigeria):

At that time, anyone recruited by the NEPA had to get his/her employment regularized by the Ministry of Establishments.

(Extract from interview notes)

This meant there had to be a good cordial working relationship for things to move on smoothly. Indeed, the government (through the Ministry of Establishment) as well as the NEPA had several joint projects. As such, policy makers involved in taking decisions on electricity infrastructure on the part of the government were also major stakeholders in the business of managing the entire electrical network. Nevertheless:

...the situation however collapsed over the decades, just like many other sectors. Today, every Nigerian suffers the effect of a system where policy makers (who are not competent on the subject matter) parade themselves as 
subject matter experts, and take decisions without consulting other stakeholders who have the requisite knowledge and experience.

(Extract from interview notes)

Indeed, the lack of competencies and deficiencies in stakeholder engagements in the Nigerian energy sector is reflected by (Dur, 2001; Durand, 2000):

- Improper audits of the electrical network infrastructure before they were sold.

- Sale of power plants and other electrical network infrastructure to individuals and companies who do not understand the dynamics of energy business.

- Inconsistencies in policy direction on the electrical power sector; among others.

\subsection{Expectations - past, present, and future expectations from the energy industry}

In considering the expectations from within the energy industry, one is pulled towards the trust, confidence, and belief that stakeholders (including energy providers and consumers) have in a future direction to travel relating to energy supply and demand. Some of these expectations may include: moderate and affordable energy bills; security of energy supply; and non-disruption; to name only a few (Reddy et al., 2000; Toth and Rogner, 2006)

There were many industries in Nigeria in the early 1970s, mainly because industrialization was at its peak at that point (Ogundele et al., 2014). Electricity demand was growing, and there was need for fidelity to the implementation of the 
national planning agenda on electrical power in order to ensure that industries and the industrialization process were supported (Stern and Kander, 2012). Planning had been in place since the 1920s that set out a route for the future growth of energy demand and consumption. Most of the national planning that was done in Nigeria were done during the colonial times (Marcellus, 2009). After the 1970s, Nigeria experienced a massive de-industrialization caused not only by the impact of some decisions under the military rule (such as divesting from agriculture and focussing on oil as the major economic resource), but also by insufficient supply of electricity to meet the growing industrial demand and growth projections. As such, energy consumption declined due to lack of electricity which led to de-industrialization (Stern, 2004).

What is currently projected as the estimated electricity demand is something very fictitious and can never reflect what the future will have to hold. This is especially true for the Nigerian case, where constant and reliable source of electricity and energy has not yet been experienced. Indeed, the provision of more energy infrastructure will stimulate a new wave of (energy) demand. More people who were not able to use certain kinds of equipment due to non-provision of electrical power will start to use them, those who have relied on local generating sets for electricity generation for their businesses will start to weigh the options of connecting to the public utility, among other interconnected factors, which will really impact on a new wave of increased demand (Sambo, 2008; Stern, 2004).

During the times of the Electricity Commission of Nigeria (ECN) and the Niger Dams Authority (NDA), electrical network infrastructure provisions were in line with the 
demand. There was clear planning, and the projections and plans were followed. As such, demand and supply of electrical energy were commensurate. As population grew, improperly formed policies ended up as the real bottle-neck to the advancement and provision of new energy infrastructure to meet the rising level of demand (DFID, 2002):

It should be noted that demand for energy (particularly electricity) was quite low at some point in the history of Nigeria. The focus was more on electrical energy requirements for lighting in residential areas, and for a few workshops and industries.

(Extract from interview notes)

However, the oil boom in the 1970s led to a growth in the demand for energy in the following ways:

- There were more industries springing up during that period (particularly textile industries), thus, increasing industrial demand for electricity infrastructure (Ogundele et al., 2014).

- The establishment of more petrochemical industries (Abdullahi and Galadima, 2014).

- Increased demand for residential use outside of lighting applications.

- More enrolment into schools (which meant improved knowledge of the importance of energy access as well as the need to provide electricity to schools for teaching, learning, and research).

- Improved living standards and earnings of the Nigerian people 
- Explosion in academic activities.

- Lots of structures and industries springing up.

- People striving to improve their comfort levels.

While growth in demand was being experienced, the installed capacity of the electrical network infrastructure remained static as there were no new investments for some decades. In recent times, the electrical supply network has been overstretched as the capacity is limited. Throughout the no-show decades, the only project that was done was the Lagos thermal station (Egbin gas turbine project) which started in 1986 and was completed in 1996, making it the biggest thermal power station in Nigeria. The Egbin power plant was built after almost 30 years of provision of the major hydro power plants (Shiroro and Kainji). Even with the provision of the Egbin power plant, demand was still far greater than supply (Oladipo and Olowu, 2014):

Nigeria experienced a null period from the mid-1980s to the early 2000s. During this period, the only power plant that was commissioned was the Shiroro hydro power plant. No improvement was done on the network infrastructure, neither was there any plan or budget for electrical network infrastructure improvement.

(Extract from interview notes)

Several studies have shown that what Nigeria needs is a diversified energy mix. Nigeria has ample primary energy resources that can be used for electricity generation which are not currently well explored (some of them were explored in the past and later abandoned). Power plants can be built using different energy 
resources with focus on siting the plant close to where the resources are located (coal fired plants in Enugu and environs, hydro power around the Mambila plateau, gas fired power plants around the Niger Delta region, among others). These opportunities have led to the entry of many global energy players to Nigeria as the energy market is huge, very much untapped, and quite promising (USAID, 2015). The viability of current and future investments in this sector is a major motivating factor for investors despite regulatory challenges.

\subsection{Legislation - institutionalized (and unwritten) rules/procedures.}

Energy legislation deals with setting out regulatory frameworks for the governance of the energy industry and the energy market (Thomson, 2010). These regulatory frameworks come in the forms of: national electricity laws which establishes obligations for the electricity network and the national electricity market (Outhred, 2004); national energy retail law which provides a schedule that regulates the sale and supply of energy to retail customers; and national gas law which establishes obligations for gas wholesale market and gas pipelines (Kenny et al., 2013). These regulatory framework forms part of the constitutive elements of the institutionalized (and unwritten) rules in the governance of the energy market.

Indeed, inasmuch as there are federal laws governing the activities of the energy supply and extractive industry, the internal mechanisms and dynamics of policy decisions at the state and federal levels also impacts (to some extent) on the workings of the energy industry. At federal level, members of the legislature can propose, and sponsor bills. They explore all sorts of mechanisms and lobbying processes to ensure the bill they sponsor is passed to law. At state level, most bills 
originate from the executive arm of the state government. The bills are then passed to the state legislature for the legislative process that gets the bills to become laws (Khemani, 2001). The state legislatures have very limited powers to recommend possible projects and ideas through bills. When they try, the state executive interprets it as an infringement on their responsibility, and also as a message that they are incompetent. This is one of the causes of friction between most state legislative assemblies and the state executive (Mba, 2014). It is obvious that at the state level, political powers lie more in the executive arm for policy formulation and implementation. Indeed, key players in the energy industry capitalize on these internal workings to explore the best lobbying mechanisms to deploy in gaining some sort of advantage, both at the federal and state levels, in addressing their issue position. However, there is still a lack of clarity regarding people's expectations from legislators at state level that needs further consideration:

Nigerians expect so much from the state legislators, not realizing that they (the people) stripped them (the state legislators) of everything that can make them influence the decisions and happenings as regards the governing of the state. The only way they can influence decisions is by frustrating the passage of a bill.

(Extract from interview notes)

Lagos is the only state where the budget and spending of the legislature is autonomous and independent of the state executive (governor) for approval. In all the other states of the federation, the governor has to approve the spending and budget of the state legislature. There are usually frictions between the two arms of government at the state level that are caused by the lobbying process(es) employed 
by either party to satisfy their interests. When the executive governor needs a bill to be passed to law that is being frustrated by the state legislator, he/she can decide not to approve their budget or spending, thus, using that as a tool for lobbying and vice versa (Mbaya et al., 2013).

The aforementioned systems also affect policy decisions in the energy supply and extractive industry. It is all a question of satisfying the interests of stakeholders in that sector. The politics of interests really come to play when there are no clear policies, guidelines, or frameworks on the ground to support certain investments or infrastructure provisions. What really happens is that the investing parties, through some lobbying mechanisms, use government instruments to make pronouncements to their favour. This sort of unwritten rule or manner of acting in order to channel decisions in favour of a few parties is something that characterizes this sector. But what happens to those who do not have strong formal/informal links to government and the political space? How does a 'normal' investor understand these underlying dynamics by looking only at market indices? These are some of the interesting challenges new investors in this sector are faced with (Ploch, 2013).

\subsection{Future visions - future visions of the energy industrylenergy market}

Future visions of the energy systems entail a variety of regulatory, technological, social, economic, and political aspects that shape what actors want, and/or think likely, in the future (World Economic Forum, 2013). Consequently, future energyrelated visions are intimately connected to development, growth, and the lifestyles of people. Indeed, energy visions are the product of continuous thought on how to address a range of energy and society issues, such as: inefficient centralized power 
plants, energy pollution, and expensive energy (Business Roundtable, 2013; Canadian Electricity Association, 2014).

It is argued that the energy futures of many nations is likely to include: distributed, accessible, digital, and connected energy sources (Dennison, 1995). However, in what way are Nigerian policy makers tackling this issue? There was very limited action for a while by policy makers in tackling the challenges facing the energy sector (Qureshi, 2011). Successive Nigerian governments had the mind-set that appointing new energy ministers and directors at the helm of affairs of major institutions was what was required to address these major challenges. However, the situation only worsened as there were insufficient competencies across the workings of the energy industry. Policy makers adopted a blame culture, rather than focusing on addressing the core issues in the electricity sector in particular (and the energy sector in general) and as such, the problem was only aggravated (Hood et al., 2002). No serious attempts were made to correct the anomalies, and new power plants were not built to accommodate the increased demand either. However, these anomalies open up new frontiers of opportunities for more (public and private) stakeholders with business interests both at present and in the future (IEA, 2012).

Paving the way for the effective future governance of the energy and electricity market started more seriously in 2005:

After a long period, there were some serious attempts made in 2005 , with a clear roadmap in correcting the anomalies which led to the electrical power sector reforms. 
(Extract from interview notes)

However, the reforms were placed on hold as the President that came into power in 2007 hailed from a region of the country where it was believed that energy and electricity provision is, and should be, the sole responsibility of the government. The belief was that if the sector eventually became privatized, energy bills would skyrocket and many Nigerians would consequently be unable to afford it. This led to a halt in the process of implementation of the roadmap for some years until the Goodluck Jonathan administration managed to complete the first phase of the privatization of the electrical power utilities and network (Official Gazette, 2005). However, some quarters argued that there were some fundamental errors with the reforms and the process of privatization, some of which includes:

- $100 \%$ sale of existing power plants.

- No new investments in infrastructures to compete with the existing companies/plants.

- Various parts of the electrical power network was sold to businessmen and not to those who have knowledge of energy/electricity supply business.

- Initial audit that was done before the privatization was carried out in a hurry and did not capture all of the various aspects of the electrical power network infrastructure challenges.

- The external investors failed to carry out their own independent audits to ascertain the value of the electrical network infrastructure before purchasing them.

- Electrical power network infrastructures were sold at very cheap rates. 
It is also argued that some of the errors were even extended to electrical network infrastructure provision:

Some interesting things (which form part of the effects of ineffective planning) were the building of power plant (Omotosho power plant in Ondo state, Southwest Nigeria) without consideration for gas infrastructure to power the electrical power plant.

(Extract from interview notes)

During the decades of non-provision of new energy supply infrastructure, there was also the challenge of non-investment in the periodic maintenance of power plants (Kumar et al., 2012). This led to a further drop in the overall efficiency of most of existing Nigerian power plants to about $50 \%$. Due to the increased demand and the inability to cope in terms of supply, backup power plants were brought to the mainstream. Even with that additional backup supply, the demand for electrical energy still outweighed the supply by far (Sambo, 2008). Nevertheless, this challenging situation was talked about in the interviews as also representing an opportunity for new businesses such as:

- Businesses involved in energy conservation, management, and efficiency services.

- Original Equipment Manufacturers (OEMs) involved in production and sale of various products and equipment for building and revamping the electrical power network. 
- Consultants and energy experts who can assist government in the area of policy direction and effective implementation of such policies to serve as key driver of investment, and provision of the required infrastructure.

The interviewees were thus keen to emphasize that the future was still bright in Nigeria. These sorts of business opportunities were believed to be a major incentive, especially for international energy-related companies who were interested in having a (or expanding their presence in Nigeria.

\subsection{Recruiting experts - recruiting new energy and public policy makers.}

Public policy essentially entails customary and institutional (written and unwritten) laws channelled towards achieving public common good. It is a means employed by governments to maintain public order and to serve their citizens guided by constitutional rules (Cockrel, 1997). The term 'public policy' is used to describe a collection of mandates, regulations, or laws, established through a political process. Energy policies are subsets of public policies and are comprised of rules, regulations, mandates, and laws promulgated to govern the affairs of the energy industry and the energy market (Supple and Sheikh, 2010). These rules and mandates are promulgated through a political process. For this reason, it is crucial to have competent experts, in the public policy space in general, and the energy policy space in particular, in order to ensure the most appropriate laws are promulgated that can serve a nation's citizens whilst protecting the common good (IEA, 2012).

The challenges in the Nigerian energy sector led different stakeholders to carry out extensive studies on what needed to be done to address the problems being 
confronted (European Commission, 2013). The first democratically elected president, after almost three decades of military rule, tried to tackle this in different ways. After several trials of different packages of solutions, a crucial (and quite evident) step taken was the recruitment of new people into the public policy space to help drive the affairs of the various sectors of the Nigerian economy (Edwards, 2008):

The Olusegun Obasanjo's administration paid attention, after almost six (6) years of learning, on the need to recruit the right subject matter experts to run the affairs of the energy sector.

(Extract from interview notes)

At that time, he appointed a very experienced and knowledgeable person as the energy minister. This recruitment, among other similar recruitments, saw the preparation and advancement of the electrical power sector reform roadmap which became the template for the eventual implementation of the sector reforms and privatization. Unfortunately, the time left during his administration was not enough to see through the entire process of the reforms. This same idea of recruiting subject matter experts into policy making by the then president was also replicated in other ministries and government agencies. As such, for the very first time, Nigeria had a new set of technocrats managing the different aspects of its economy, with the very strong backing and support of the recruiter, the president. This led to progress in the economy and other aspects of the life of Nigeria, including growth in GDP, trade and investments, among others. It is worthy of note that those recruited into the fabrics of the decision making process during this period are currently handling much more responsibilities in the country's polity and are now major stakeholders in the 
country's affairs. It should also be noted that some of the interviewees expressed their displeasure at the initial appointment of certain appointees on the grounds of inexperience in political affairs. However, at the point of the interviews, they did acknowledge that it was one of the best things that happened to Nigeria.

With reference to the interviews conducted, there are three resounding features that the interviewees stressed as the guiding principles (despite all interests) for preparing or drafting a policy at the federal level:

- Non infringement on human rights

- Non adverse effect on the environment

- A view on sustainable development

The politics of decision making and the recruitment of the right policy instruments are quite fundamental in effecting any positive change. The learnings from the affairs of the Olusegun Obasanjo's administration have been tried by a few successive administrations. However, what worked well for him were his strong military background, and the firm political backing he gave to his recruitees which enabled them function freely in their respective roles.

\subsection{Interconnections between the various intra-country induced influences}

Figure 1 shows how the various intra-country induced influences are interconnected. It all starts with recruiting experts with the right competencies. Having competent players lead to a better understanding of the expectations, which enables more appropriate energy decisions and legislation to achieve the desired future visions. 
Achieving the desired future visions requires recruiting experts with the right competencies. It is also worth highlighting that whilst figure 1 does well in reiterating some of the main links between each of the five intra-country specific themes, it is important to emphasize that all the themes are intimately connected to one another, and hence the actual picture is much messier than what could be inferred from figure 1.

\section{INTER-COUNTRY INDUCED INFLUENCES ON NIGERIA'S ENERGY INDUSTRY PERFORMANCE}

This section presents three major (external) inter-country induced factors influencing the Nigerian energy industry performance:

1. The changing dynamics of international and foreign aid.

2. United Nations Sustainable Development Goals.

3. Paris agreements on Climate Change.

These are not the only influences by any means, but did emerge from the analysis as being particularly salient (in terms of impact on Nigerian energy legislation and governance dynamics).

\subsection{The changing dynamics of international and foreign aid}

According to the interviewees, the changing dynamics of international and foreign aid is indirectly affecting the Nigerian energy decision dynamics. Traditionally, 
international and foreign aid had the sole objective of promoting welfare and economic development in developing countries (Abugre Charles, 2010). Most international aid has a grant element. However, the aid landscape is currently undergoing a major international rethink (Carbonnier and Sumner, 2012). Some countries are changing their paradigm towards aid and are currently exploring possible alternatives to international aid and cooperation. Indeed, nations and aid givers are re-questioning the aims and scope of aids.in many fora. The global aid landscape is currently undergoing significant changes due to three major factors (Carbonnier and Sumner, 2012):

1. There is a global shift in the geography of poverty: In the past, the vast majority of the world's poor lived in least developed countries. Today, it has shifted to middle-income countries (Carbonnier, 2012). This shift definitely impacts on international aid dynamics as priorities, scope, and scale have to be redefined.

2. There is a growth of new global aid donors: The past decades have seen a growth of number of international aid donors, which is creating competition amongst them in addressing development challenges across the world. The rise in number of international aid donors is also impacting on the existing donors redefining their aid priorities and scope (Ranis, 2012).

3. There are redefined international cooperation agenda: This links to point 2 above. The drive to address issues of global common good, and the quest to fight global and regional common ills, has led to the multiplication of international donors and agencies. These agencies target the promotion and financing of projects that addresses issues of global common good, or fighting common ills, such as, climate change, environmental degradation, global 
public policies, poverty reduction, and other developmental agenda (World Economic Forum, 2010). These developmental agenda are expressed in the United Nations Sustainable Development Goals.

In Nigeria, the changing landscape of energy legislation and governance have been influenced by the presence and actions of some international aid agencies, such as, the World Bank, African Development Bank, the German Development Cooperation (Deutsche Gesellschaft fur Internationale Zusammenarbeit - GIZ), the United Kingdom Foreign and Commonwealth Office (UK-FCO), among others. They contributed to the implementation of the power sector reforms by setting conditions upon which they can provide aid and investment support in the electricity sector. Indeed, the $\mathrm{GIZ}$ have contributed to ensuring that a proper policy framework to encourage investments in large on-grid and off-grid renewables is framed, which is where they intend to channel their aid support (Federal Ministry of Power, 2014). Most international aid in the Nigerian energy sector is channelled towards fulfilling some UN Sustainable Development Goals, such as, clean energy and climate action (UNDP, 2015).

\subsection{United Nations Sustainable Development Goals}

The interviewees acknowledged the impact of the United Nations Development Programs as a major contributor to the changing dynamics of infrastructure decisions and governance (including energy). They stressed that the Millennium Development Goals of the United Nations shaped government priorities with respect to infrastructure investments and government policies. 
The United Nations development targets expressed in the Sustainable Development Goals (SDGs) cannot be achieved without careful consideration of the role of energy. Indeed, all seventeen SDGs have varying degrees of impact on energy. However goals, such as climate action, affordable and clean energy, responsible production and consumption, clean water and sanitation, and sustainable cities and communities, have more direct impact on energy infrastructure decisions and governance at country level (Shittu, 2016). Taking action on implementing these goals at country level may require fundamental changes in setting national energy priorities, or redefining the energy mix in order to ensure that a good proportion of the energy, generated and used, comes from clean (renewable) sources (Shittu, 2016). Indeed, the newly set SDGs by the United Nations constitute one of the deciding elements being considered by most foreign and international aid donors as a condition for Nigeria (and other nations) to benefit from aid. This is gradually impacting on the landscape of the energy infrastructure and governance nexus in Nigeria, thus, enabling a transition towards implementing actions that addresses the SDGs.

\subsection{Paris agreements on Climate Change}

The Paris agreement on climate change was negotiated and finalized in Paris in 2015. It is the new global architecture developed to fight climate change and its impact. The interviewees stressed that the Paris agreement on climate change is likely to shape Nigeria's thinking with respect to energy governance. In particular, meeting carbon mitigation targets, and the nationally determined contributions, requires a rethink in the energy governance system and structure. 
Climate change concerns, and mitigating against its effects, requires a different way of thinking with respect to energy infrastructure choices and energy governance. Indeed, implementing the Paris Agreements on Climate Change may require a certain level of energy competence, and a different way of thinking with regards to energy legislation, which may not be the case today (United Nations, 2015). International pressures towards taking climate action may require fundamental structural changes in energy legislation and decision dynamics at country level. For Nigeria, this may mean creating a unit at the federal level to focus on the implementation of climate related commitments. No doubt, implementing climate action is gradually impacting on Nigeria's energy decisions and energy governance.

\section{DISCUSSIONS, CONCLUSIONS, AND POLICY IMPLICATIONS.}

The case presented in this paper focussed on the influences that underlie the process and practice of policymaking in relation to Nigerian energy supply infrastructure provision and energy policy. Transition in energy use and energy policy has several consequences such as: economic consequences (Barker, 2009; Lutz, 2014), which tends to undermine the high costs and low incentives (in the short term) of investments in effecting a shift of energy technology in use; the (apparent) halt in revenues and customers; and social consequences (Stirling, 2014), which tend to undermine its impacts on people's lifestyles with respect to appliance usage, transport, industry and commerce, types of houses they live in, income and expenditure, and the environment (Reddy et al., 2000). These consequences are often results of the various influence mechanisms highlighted in section 4 (Heldeweg et al., 2015). 
The decision making processes and dynamics employed in the governance of energy infrastructure provisions can either foster the provision of the needed infrastructure, following the right energy mix, or increase the energy vulnerability of the given geography or society. The influences highlighted (in sections 4 and 5) have corresponding consequences across serial interconnected areas particularly in energy planning, energy security, energy pricing (including taxes and tariffs), energy access, and energy market structure governance issues (Joskow, 2003). The economics of energy plays a vital role in shaping energy policy which present themselves in the forms of: subsidies and regulations that affect prices of the various forms of energy; market forces; taxes; environmental; and societal costs (Thollander and Palm, 2013).

The historical policy decision dynamics have been the major factor that influenced the transition in the Nigerian energy policy, driven by the policy focus within the different stages/phases in energy policy direction. This highlights the increasing role of public institutions and powerful actors (policy makers) in the governance of energy resources and infrastructure provision (Edomah et al., 2016b; Ulli-Beer, 2013).

Indeed, this study reveals five major intra-country influences affecting the Nigerian energy industry performance which are: competencies; expectations; legislation; future visions; and recruiting experts. The complexities around policy decisions on energy infrastructure provisions reflect the lack of requisite competencies on the part of energy policy makers, which has contributed greatly to past and present challenges of the Nigerian energy sector. It can be argued that the root cause of some of the intra-country induced influences, such as, competencies and recruiting 
experts, stems from: nepotism arising from tribalism, favouritism for political party affiliates; and corruption. Indeed, the case of unwritten rules and procedures provides a fertile ground for breeding and institutionalizing corruption in the sector (Edomah et al., 2016b) .

The absence of a systematic way of recruiting new players to the policy space poses some concerns on the future governance of the affairs of the energy sector. Considering the growing demand for energy, and the slow pace of energy infrastructure provisions to meet the rising demand, there are concerns if the current policy decision structure is capable of driving the required changes needed to meet both current and future energy demand. This confirms that policy governance structure plays a vital role in energy supply security, which in turn affects other sectors that relies on energy such as residential, transportation, and industry sectors.

Although this paper focuses on the Nigerian case, there are similarities with other developing African countries with respect to energy governance challenges. The power sector dynamics across many African countries is becoming increasingly complex, which impacts on energy legislation systems (Bellantuono, 2010). The socio-technical complexity of energy infrastructure is highly impacted by domestic, national, and regional demand (Houwing et al., 2007). Corruption prominent across most countries in Africa, with around $60 \%$ of the African countries classified as being highly corrupt (Bray, 2015).

This study highlights the need for policy makers to have the right competency set. For those that may be deficient, stakeholder engagement and expert consultation 
provides a platform for a quick win. This could help them to also identify stakeholders they can trust, such that they can, together, make strategic energy plans that can help Nigeria move towards a more desirable energy future. However, there are also social and institutional elements which policy makers need to consider (however competent they are) in order to achieve the target goal, and hence the system in which the policy makers and energy experts are operating within also needs to evolve.

The challenge of unclear policies and some unwritten rules poses a business risk to current and future investors in the sector. However, the current business opportunities far outweigh the current regulatory challenges as the Nigerian energy market is huge and very much untapped. This study brings further questions to the fore that needs to be explored by further research such as: the actual linkages and impacts between energy policy governance and energy infrastructure provision; as well as the (un)intended consequences of policy decision process/dynamics on the energy industry.

Finally, there is a need for the Nigerian government to define the energy infrastructure and governance nexus in order to limit the effects of unintended consequences, as a country's total infrastructure stocks (including energy) also contributes to its GDP. This means setting clear rules and defining (technical and policy) regulations for the effective governance of the (local) energy industry and energy infrastructure provisions. This can be done by understanding and influencing, through regulations, institutional rules that govern the workings of institutional actors 
in energy supply infrastructure provision within institutional and structural frameworks.

\section{Funding}

This research did not receive any specific grant from funding agencies in the public, commercial, or not-for-profit sectors.

\section{REFERENCES}

Abdullahi, A.S., Galadima, W., 2014. Petrochemicals and Economic Development: Issues and Challenges. Acad. J. Interdiscip. Stud.

doi:10.5901/ajis.2014.v3n5p47

Abugre Charles, 2010. Why foreign aid is important for Africa [WWW Document]. African Voices. URL http://edition.cnn.com/2010/OPINION/08/13/aid.africa.abugre/ (accessed 11.11.16).

Alberta Energy Regulator, 2015. Alberta Energy Regulator Stakeholder Engagement Framework. Alberta Energy Regul.

Bale, C.S.E., Varga, L., Foxon, T.J., 2015. Energy and complexity: New ways forward. Appl. Energy. doi:10.1016/j.apenergy.2014.10.057

Barker, T., 2009. The Macroeconomic Effects of the Transition to a Low-Carbon Economy. Break. Clim. Deadlock Brief. Pap.

Bellantuono, G., 2010. Comparing regulatory decision-making in the energy sector. Comp. Law Rev.

Bray Jonathan, 2015. Navigating corruption in Africa's power sector. African Bus. Mag.

Bromley, S., Busby, J., Duquet, N., Nelson, L., Utting, P., Ives, K., 2006. The International Politics of Oil. St Antony's Int. Rev.

Business Roundtable, 2013. Taking Action on Energy: A CEO Vision for America's Energy Future. Bus. Roundtable.

Canadian Electricity Association, 2014. Vision 2050: The future of Canada's Electricity System. Can. Electr. Assoc.

Carbonnier, G., 2012. The new geography of poverty: What does it mean for development aid?

Carbonnier, G., Sumner, A., 2012. Reframing aid in a world where the poor live in emerging economies. Rev. Int. Polit. développement. doi:10.4000/poldev.977

Caron, G., Paradis, C., 2011. National Energy Board Report on Plans and Priorities. 
Natl. Energy Board.

Clausen, A.S., 2012. The individually focused interview: Methodological quality without transcription of audio recordings. Qual. Rep.

Cockrel, J., 1997. Public Policy making in America. Coop. Ext. Serv.

Conde, C., Lonsdale, K., Nyong, A., Aguilar, Y., 2004. Engaging Stakeholders in the Adaptation Process. Adapt. Policy Fram. Clim. Chang. Dev. Strateg. Policies Meas.

Connors, S.R., 2015. Issues in Energy and Sustainable Development. AGS Mapp. Proj. White Pap. - Energy.

Dennison, J., 1995. Challenge and Opportunity: Charting ba new Energy Future. Energy Futur. Coalit.

DFID, 2002. Energy for the poor: Underpinning the Millenium Development Goals. Dep. Int. Dev. doi:10.1017/CBO9781107415324.004

Dineen, D., Howley, M., Holland, M., 2014. Energy in Transport - 2014 Report. Energy Policy Stat. Support Unit, Sustain. Energy Auth. Irel.

Doukas, A., Ballesteros, A., 2015. Clean Energy Access in Developing Countries: Perspectives on Policy and Regulation. Keys To Achiev. Univers. Energy Access Ser.

Doukas, H., Patlitzianas, K.D., Kagiannas, a. G., Psarras, J., 2008. Energy Policy Making: An Old Concept or a Modern Challenge? Energy Sources, Part B Econ. Planning, Policy. doi:10.1080/15567240701232378

Dur, R.A.J., 2001. Why do policy makers stick to inef cient decisions? Public Choice.

Durand, T., 2000. Forms of incompetence. Theory Dev. Competence-Based Manag.

Edomah, N., Foulds, C., Jones, A., 2016a. Energy transitions in Nigeria: The evolution of energy infrastructure provision (1800-2015). Energies. doi:10.3390/en9070484

Edomah, N., Foulds, C., Jones, A., 2016b. The Role of Policy Makers and Institutions in the Energy Sector: The Case of Energy Infrastructure Governance in Nigeria. doi:10.3390/su8080829

Edwards, J.S., 2008. Knowledge management in the energy sector: review and future directions. Int. J. Energy Sect. Manag. doi:10.1108/17506220810883216

European Commission, 2013. Energy challenges and policy.

European Union, 2015. EU energy governance. House Lords Eur. Union Comm.

Federal Ministry of Power, 2014. The Nigerian Energy Sector: An Overview with a Special Emphasis on Renewable Energy, Energy Efficiency and Rural Electrification. Niger. Electr. Support Proggramme.

Florini, A., Sovacool, B.K., 2009. Who governs energy? The challenges facing global energy governance. Energy Policy. doi:10.1016/j.enpol.2009.07.039

Goldthau, A., 2014. Rethinking the governance of energy infrastructure: Scale, decentralization and polycentrism. Energy Res. Soc. Sci.

doi:10.1016/j.erss.2014.02.009 
Great Britain Department of Trade and Industry, 2003. Our energy future - creating a low carbon economy, Energy White Paper.

Halcomb, E.J., Davidson, P.M., 2006. Is verbatim transcription of interview data always necessary? Appl. Nurs. Res. doi:10.1016/j.apnr.2005.06.001

Heldeweg, M. a, Sanders, M., Harmsen, M., 2015. Public-private or private-private energy partnerships? Toward good energy governance in regional and local green gas projects. Energy. Sustain. Soc. doi:10.1186/s13705-015-0038-8

Hoffman, R., 2014. Capitalizing on energy abundance: reapeing the benefits will require a multi billion dollar investment. Interstate Nat. Gas Assoc. Am. Found.

Hood, C., Lodge, M., Clifford, C., 2002. Civil Service Policy-Making Competencies in the German BMWi and British DTI: a comparative analysis based on six case studies. London Ind. Forum 1-26.

Houwing, M., Heijnen, P., Bouwmans, I., 2007. Socio-technical complexity in energy infrastructures. Conf. Proc. - IEEE Int. Conf. Syst. Man Cybern. doi:10.1109/ICSMC.2006.384515

IEA, 2012. Joint Public-Private Approaches for Energy Efficiency Finance: Policies to scale-up private sector investment. IEA Policy Pathw. Ser. Policy.

IHS Global Inc, 2013. Oil \& Natural Gas Transportation \& Storage Infrastructure: Status, Trends, \& Economic Benefits. Am. Pet. Institutee.

Joskow, P.L., 2003. Energy Policies and Their Consequences after 25 Years. Energy J. doi:10.5547/ISSN0195-6574-EJ-Vol24-No4-2

Kenny, P., Strate, B., Hanscombe, A., Atkin, D., Kemp, A., 2013. Review of Enforcement Regimes under the National Energy Laws. Rep. Standing Counc. Energy Resour.

Khandkar, S.H., 2009. Open Coding. Cpsc. doi:10.4135/9781412963909.n299

Khemani, S., 2001. Fiscal Federalism and Service Delivery in Nigeria: The Role of States and Local Governments. Comp. Gen. Pharmacol.

Kumar, K., 2013. Conducting key informant interviews in developing countries. J. Chem. Inf. Model. doi:10.1017/CBO9781107415324.004

Kumar, N., Besuner, P., Lefton, S., Agan, D., Hilleman, D., 2012. Power Plant Cycling Costs. Natl. Renew. Energy Lab.

Kunreuther, H., Weber, E.U., 2014. Aiding Decision Making to Reduce the Impacts of Climate Change. J. Consum. Policy. doi:10.1007/s10603-013-9251-z

Lutz, C., 2014. Macroeconomic Effects of the Energy Transition. Final Rep. Summ. Proj. No. 31/13 Fed. Minist. Econ. Aff. Energy.

Marcellus, I.O., 2009. Development Planning in Nigeria: Reflections on the National Economic Empowerment and Development Strategy (NEEDS) 2003-2007. J. Soc. Sci.

Markard, J., 2011. Transformation of Infrastructures: Sector Characteristics and Implications for Fundamental Change. J. Infrastruct. Syst. doi:10.1061/(ASCE)IS.1943-555X.0000056

Mba, P., 2014. Demystifying Intra-Legislative Conflicts in Nigeria: The Senate and 
the House of Representatives, 2007-2011. Mediterr. J. Soc. Sci. 5, 677-690. doi:10.5901/mjss.2014.v5n1p677

Mbaya, P.Y., Tella, C.M., Adole, R.A., 2013. The processes of law making in a presidential system of government: The Nigerian experience. Asian Soc. Sci. doi:10.5539/ass.v9n2p106

McAdams, D.P., 1980. A thematic coding system for the intimacy motive. J. Res. Pers. doi:10.1016/0092-6566(80)90001-X

Naudé, W. a., Krugell, W.F., 2007. Investigating geography and institutions as determinants of foreign direct investment in Africa using panel data. Appl. Econ. doi:10.1080/00036840600567686

Official Gazette, 2005. Power Sector Reform Act. Fed. Repub. Niger.

Ogundele, O., Chete, L.N., Adeoti, J.O., Adeyinka, 2014. Industrial development and growth in Nigeria :Lessons and challenges. African growth Initiat. World Inst. Dev. Econ. Res.

Oladipo, F., Olowu, T., 2014. The Nigerian Power System Till Date: A Review . Int. J. Adv. Found. Res. Sci. Eng.

Outhred, H., 2004. The Evolving Australian National Electricity Market: An Assessment. Power Prog. An Audit Aust. Electr. Reform Exp.

Platzer, L., 2015. The Politics of Urban Energy Transitions - Analyzing the ' Green City ' Freiburg and Its Political Actors. Univ. Twente.

Ploch, L., 2013. Nigeria: Current Issues and U.S. Policy. Congr. Res. Serv. Rep. Congr.

PWC, 2013. Shale oil: The Next Energy Revolution. PriceWaterHouse Coopers.

Qureshi, Z., 2011. the Role of Public Policy in Sustainable Infrastructure. Glob. Econ. Dev. Brookings Inst.

Ranis, G., 2012. Another Look at Foreign Aid.

Reddy, A.K.N., Annecke, W., Blok, K., Bloom, D., Boardman, B., Eberhard, A., Ramakrishna, J., Wodon, Q., Kaniz, A., Zaidi, M., 2000. Energy and Social Issues. World Energy Assess. Energy use Chall. Sustain.

Sambo, A., 2008. Matching electricity supply with demand in Nigeria. Int. Assoc. Energy Econ.

Schock, R.N., Sims, R.E.H., 2007. Energy Supply. Clim. Chang. 2007 Mitigation. Contrib. Work. Gr. III to Fourth Assess. Rep. Intergov. Panel Clim. Chang.

Scott, C.A., Pierce, S.A., Pasqualetti, M.J., Jones, A.L., Montz, B.E., Hoover, J.H., 2011. Policy and institutional dimensions of the water-energy nexus. Energy Policy 39, 6622-6630. doi:10.1016/j.enpol.2011.08.013

Sherriff, L., 2012. Delivering Renewable Energy Projects through Stakeholder Engagement. Electr. Eng. Assoc. Conf. Trade Exhib.

Shittu, J., 2016. Prioritizing Targets For Implementation: Which Way Forward For Nigeria. Towar. Achiev. Sustain. Dev. All.

Stern, D.I., 2004. Economic Growth and Energy. Encycl. Energy. 
Stern, D.I., Kander, A., 2012. The Role of Energy in the Industrial Revolution and Modern Economic Growth. Energy J. doi:10.5547/01956574.33.3.5

Stevens, P., Hulbert, M., 2012. Oil Prices: Energy Investment, Political Stability in the Exporting Countries and OPEC's Dilemma. CHATHAM HOUSE EEDP Program. Pap.

Stirling, A., 2014. Transforming power: Social science and the politics of energy choices. Energy Res. Soc. Sci. 1, 83-95. doi:10.1016/j.erss.2014.02.001

Supple, D., Sheikh, I., 2010. Public Policies Driving Energy Efficiency Worldwide. White Pap. - Johnson Control. Inc.

Tansey, O., 2007. Process Tracing and Elite Interviewing: A case for nonprobabilitysampling. PS Polit. Sci. Polit. doi:10.1017/Si049096507071211

Thollander, P., Palm, J., 2013. An Interdisciplinary Perspective on Barriers, Energy Audits, Energy Management, Policies, and Programs. Improv. energy Effic. Ind. energy Syst.

Thomson, A., 2010. Legislation in the UK energy industry. ARUP.

Toth, F.L., Rogner, H.-H., 2006. Oil and nuclear power: Past, present, and future. Energy Econ. doi:10.1016/j.eneco.2005.03.004

Ulli-Beer, S., 2013. Dynamic Governance of Energy Technology Change: Sociotechnical transitions towards sustainability. Springer. doi:10.1007/978-3-64239753-0

UNDP, 2015. Sustainable Development Goals [WWW Document]. United Nations Dev. Program. URL http://www.undp.org/content/undp/en/home/sustainabledevelopment-goals.html (accessed 11.11.16).

UNEP, 2011. Beyond the Talk: Engaging Stakeholders in Bioenergy Development. Bioenergy Issue Pap. Ser.

United Nations, 2015. Paris Agreement. United Nations/Framework Conv. Clim. Chang. doi:FCCC/CP/2015/L.9

US EPA, 2016. Reduce the Environmental Impact of Your Energy Use.

USAID, 2015. Investment Brief for the Electricity Sector in Nigeria. Power Africa.

Van Vooren, B., 2011. Legal and Institutional Obstacles to an EU External EU Energy Policy post-Lisbon: Managing the Vertical and Horizontal Axes. 6th ECPR Gen. Conf.

Verrastro, F. a, Ladislaw, S.O., Frank, M., Hyland, L. a, Schlesinger, J.R., 2010. The Geopolitics of Energy - Emerging Trends, Changing Landscapes, Uncertain Times. A Rep. CSIS Energy Natl. Secur. Progr.

We Energies, 2015. Understanding Demand Charges for General Secondary Rates. We Energies.

Whitmarsh, L., Swartling, Å.G., Jäger, J., 2009. Participation of experts and nonexperts in a sustainability assessment of mobility. Environ. Policy Gov. doi:10.1002/eet.513

World Economic Forum, 2013. Energy Vision 2013 Energy transitions : Past and Future. World Economic Forum, Geneva, Switzerland. doi:070113 
World Economic Forum, 2010. Everybody's Business: Strengthening International Cooperation in a more Interdependent World. A Rep. Glob. Redesign Initiat.

WSJ, 2014. 5 Reasons the World Is Not Running Out of Resources [WWW Document]. Wall Str. J. URL http://blogs.wsj.com/briefly/2014/04/25/5-reasonsthe-world-is-not-running-out-of-resources/ (accessed 11.21.16). 
Table 1. Details of selected research participants and interview dates

\begin{tabular}{|c|c|c|}
\hline $\begin{array}{c}\text { Research } \\
\text { Participants }\end{array}$ & Background/expertise & Date of interview \\
\hline A & $\begin{array}{l}\text { An experienced socio-political expert and economist. He } \\
\text { was once a senior special adviser to the president on } \\
\text { policy implementation. He has been working and } \\
\text { consulting for the government for over } 20 \text { years. }\end{array}$ & $13^{\text {th }}$ June 2015. \\
\hline B & $\begin{array}{l}\text { A senior politician with over } 15 \text { years' experience in the } \\
\text { art of policy making. He was once a special assistant to } \\
\text { an executive governor. He later moved to the Federal } \\
\text { House of Representatives as a law maker where he } \\
\text { chaired the house committee on treatise and policy for } \\
\text { several years. }\end{array}$ & $20^{\text {th }}$ June 2015. \\
\hline C & $\begin{array}{l}\text { A politician with over } 20 \text { years' experience in politics. He } \\
\text { was a speaker of a state house of assembly for several } \\
\text { years where he chaired several policy sessions at the } \\
\text { state house of assembly. }\end{array}$ & $18^{\text {th }}$ July 2015. \\
\hline D & $\begin{array}{l}\text { A senior technical expert in energy with over } 20 \text { years } \\
\text { industry experience. He spent a large part of his working } \\
\text { career with the Transmission Company of Nigeria (TCN) } \\
\text { where he had technical responsibility for the smooth } \\
\text { operation and maintenance of a section of the country's } \\
\text { electricity grid network. }\end{array}$ & $15^{\text {th }}$ August 2015. \\
\hline $\mathbf{E}$ & $\begin{array}{l}\text { A senior energy expert with more than } 30 \text { years' } \\
\text { experience in the electrical power industry. He had } \\
\text { responsibility for the general management and } \\
\text { operations of one of the regions of the Transmission } \\
\text { Company of Nigeria (TCN). Prior to that, he worked with } \\
\text { the then National Electric Power Authority (NEPA) from } \\
\text { early } 1980 \text { s, and later the Power Holding Company of } \\
\text { Nigeria (PHCN) where he worked at senior levels. He } \\
\text { saw a large part of the policy and technical transitions of } \\
\text { the Nigerian electrical power sector during his working } \\
\text { career. }\end{array}$ & $24^{\text {th }}$ August 2015. \\
\hline $\mathbf{F}$ & $\begin{array}{l}\text { An engineer with several years' experience working in } \\
\text { the energy industry. He worked in Nigeria's biggest } \\
\text { thermal power station for several years where he } \\
\text { handled several roles. }\end{array}$ & September \\
\hline G & $\begin{array}{l}\text { A communications expert with several years' experience } \\
\text { in the energy industry. He was Head of Corporate } \\
\text { Communications for one of Nigeria's biggest electrical } \\
\text { distribution company for several years. }\end{array}$ & September \\
\hline $\mathbf{H}$ & $\begin{array}{l}\text { An engineer with several years' experience in energy } \\
\text { technology industry. He worked with some top Original } \\
\text { Equipment Manufacturers involved in manufacturing and } \\
\text { sales of power turbines and electrical network solutions. } \\
\text { He has spent a large part of his working career in } \\
\text { technology sales and marketing, interfacing with many } \\
\text { of the end users and several stakeholders in the } \\
\text { Nigerian energy sector. }\end{array}$ & September \\
\hline
\end{tabular}




\section{Competencies}

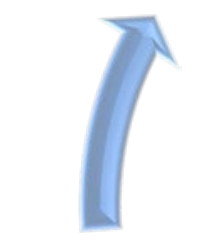

Recruiting

experts

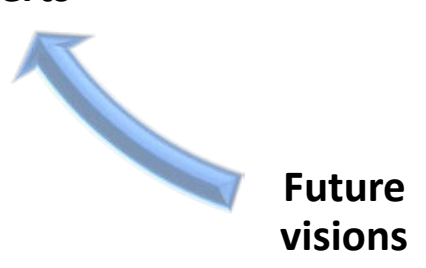

Expectations

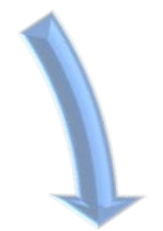

Legislation

Figure 1: The interconnections between the intra-country induced influences 


\section{Highlights}

- Unclear energy policies pose a business risk to current and future investors.

- Our energy future is threatened by unsystematic recruitment into the policy space.

- Some energy governance challenges reflect incompetence in energy legislation.

- Nigerian energy transition was shaped by historical policy dynamics and structures. 